\title{
PENGEMBANGAN BUKU AJAR EVALUASI PEMBELAJARAN
}

\author{
Rohmat Febrianto ${ }^{1)}$, Flora Puspitaningsih ${ }^{2)}$ \\ 1) STKIP PGRI Trenggalek \\ febrialbuchori@yahoo.com, florapuspita70@gmail.com
}

\begin{abstract}
ABSTRAK: Salah satu faktor penentu keberhasilan pembelajaran adalah keberadaan media dan atau sumber belajar yang mudah digunakan oleh mahasiswa. Hasil studi pendahuluan dalam proses perkuliahan Evaluasi Pembelajaran di seluruh program studi STKIP PGRI Trenggalek, mahasiswa merasa kesulitan mendapatkan buku ajar yang sesuai dengan kebutuhan perkuliahan dan ini dapat mempengaruhi hasil belajar mereka. Jika kondisi ini dibiarkan maka dapat menghambat pencapaian kompetensi perkuliahan. Tujuan penelitian ini adalah mengembangkan buku ajar evaluasi pembelajaran yang sesuai dengan kebutuhan mahasiswa serta melihat kelayakan buku ajar yang dikembangkan. Metode pengembangan buku ajar menggunakan desain model ADDIE yang mencakup: Analyze, Design, Development, Implementation dan Evaluate. Hasil penelitian dari uji ahli materi didapatkan skor persentase $82,00 \%$ dengan kategori cukup layak, hasil uji ahli media didapatkan skor persentase $84,44 \%$ dengan kategori cukup layak, hasil uji 1 kepada mahasiswa didapatkan skor persentase 80,83\% dengan kategori cukup layak, hasil uji 2 kepada mahasiswa didapatkan skor persentase 84,28\% dengan kategori cukup layak. Secara keseluruhan hasil penelitian didapatkan skor persentase $82,88 \%$ dengan kategori cukup layak. Dengan demikian buku ajar yang dikembangkan cukup layak dan dapat digunakan mahasiswa untuk mendukung proses perkuliahan.
\end{abstract}

Kata kunci : Buku, Evaluasi, Media, Pembelajaran, Pengembangan.

ABSTRACT: One of the determining factors for learning success is the existence of media and or learning resources that are easy to use by students. The results of the preliminary study in the Learning Evaluation process throughout the STKIP PGRI Trenggalek study program, students find it difficult to get textbooks that fit their lecture needs and this can affect their learning outcomes. If this condition is left alone it can hamper the achievement of lecture competencies. The purpose of this study is to develop learning evaluation textbooks that fit the needs of students and see the feasibility of textbooks developed. The method of developing textbooks uses the ADDIE model design which includes: Analyze, Design, Development, Implementation and Evaluate. The results of the research from the material expert test obtained a percentage score of $82.00 \%$ with a fairly decent category, the results of the media expert test obtained a percentage score of $84.44 \%$ with a fairly decent category, the results of the 1 test to students obtained a percentage score of $80.83 \%$ with a fairly decent category, the results of the 2 nd test for students obtained a percentage score of $84.28 \%$ with a fairly decent category. Overall results of the study obtained a percentage score of $82.88 \%$ with a fairly decent category. Thus the textbooks developed are quite feasible and can be used by students to support the lecture process.

Keywords: Book, Development, Evaluation, Learning, Media.

\section{PENDAHULUAN}

STKIP PGRI Trenggalek merupakan Lembaga Pendidikan Tenaga Keguruan yang hasil luaran lulusannya adalah calon guru. Salah satu kompetensi yang harus 
dikuasai guru adalah kompetensi paedagogik yakni kemampuan dalam mengajar yang di dalam subkompetensinya terdapat kompetensi mengevaluasi pembelajaran. Melalui mata kuliah Evaluasi Pembelajaran mahasiswa mempelajari tentang bagaimana melaksanakan evaluasi dalam pembelajaran. Mata kuliah ini secara substansial memberikan dasar konsep, teori, prinsip dan prosedur tentang evaluasi pembelajaran. Bobot mata kuliah sebanyak dua sks. Sifat mata kuliah adalah wajib tempuh dan lulus bagi mahasiswa serta menjadi prasyarat untuk mata kuliah praktik Micro Teaching.

Hasil pengamatan dalam pelaksanaan perkuliahan Evaluasi Pembelajaran, bahan ajar yang digunakan dosen untuk dimanfaatkan mahasiswa berupa buku yang substansinya kurang mengarah pada substansi mata kuliah atau silabus yang ada pada kurikulum program studi. Artinya buku-buku literatur tersebut belum menunjukkan sebagai buku ajar yang disesuaikan dengan tujuan perkuliahan dan contoh-contoh yang ada belum mampu mempermudah mahasiswa memahami materi sesuai bidang studi masing-masing.

Karakteristik buku ajar berbeda dengan buku teks. Dwiyogo (dalam Febrianto, 2012) mengungkapkan bahwa buku ajar secara khusus diorientasikan untuk pebelajar supaya mampu mengembangkan kemampuan belajar, sebab: (1) disusun menurut struktur dan isi yang sistematis, (2) menjelaskan tujuan pembelajaran, (3) menumbuhkan motivasi belajar, (4) mengantisipasi kesulitan pebelajar, (5) menyediakan rangkuman serta balikan. Pandangan ini menunjukkan bahwa buku ajar memiliki peranan yang penting sesuai eksistensinya dalam menunjang keberhasilan pembelajaran.

Keberadaan buku ajar sebagai media dan atau sumber belajar mahasiswa dalam perkuliahan pada hakikatnya untuk mempermudah mereka belajar. Diketahui bersama bahwa proses belajar terjadi baik secara langsung maupun tidak langsung. Belajar langsung berarti mahasiswa berinteraksi dengan dosen. Sedangkan belajar tidak langsung artinya mahasiswa aktif berinteraksi dengan media atau sumber belajar lain yang menunjang perkuliahan. Istiqlal (2018) menyatakan bahwa media dapat mempelancar proses interaksi antara dosen dengan mahasiswa dan membantu mahasiswa belajar secara optimal.

Berdasar pada studi pendahuluan kepada mahasiswa peserta perkuliahan Evaluasi Pembelajaran dari seluruh program studi di STKIP PGRI Trenggalek, rata-rata mahasiswa memiliki input yang cukup minimalis, mahasiswa kesulitan memahami apa yang terdapat dalam literatur atau bahan perkuliahan. Hasil wawancara dengan mahasiswa, mereka mengharapkan adanya media sebagai sumber belajar yang mudah dimanfaatkan dan sesuai dengan perkuliahan. Bagi mahasiswa literatur yang digunakan selama ini belum mampu mengakomodasi kebutuhan belajar karena bersifat parsial sehingga mereka masih merasa kesulitan dan hal ini dapat berpengaruh pada hasil belajar mahasiswa. Apabila kondisi ini dibiarkan maka dapat menghambat mahasiswa mencapai kompetensi mata kuliah. Berangkat dari permasalahan itu, perlu solusi pemecahannya yakni dengan mengembangkan buku ajar yang didesain secara sistematis sesuai dengan 
model desain sistem pembelajaran sehingga hasilnya sesuai dengan kebutuhan dalam perkuliahan.

Mengacu pada permasalahan yang ditemukan maka tujuan dari penelitan ini adalah mengembangkan buku ajar evaluasi pembelajaran yang sesuai dengan kebutuhan mahasiswa serta melihat kelayakan buku ajar yang dikembangkan. Sehingga hasilnya mampu mengakomodasi kebutuhan belajar mahasiswa dengan produk buku ajar yang layak sebagai media atau sumber belajar.

Urgensi buku ajar sebagai media dalam proses pembelajaran jika ditinjau dari sisi pebelajar dapat dilihat dari fungsi dan manfaatnya. Umarella, dkk. (2018) mengemukakan bahwa pemilihan dan penentuan media pembelajaran yang tepat sesuai kebutuhan akan membuat media semakin urgen digunakan. Terkait fungsi dan manfaat buku ajar, Prastowo (2013) mengemukakan bahwa fungsi buku ajar yakni pebelajar dapat: (1) belajar mandiri, (2) belajar kapan dan dimana saja, (3) belajar sesuai kecepatan masingmasing, (4) mempelajari materi sesuai pilihannya, (5) mengarahkan aktivitas belajar sesuai kompetensi. Manfaat bahan ajar diantaranya yakni (1) pembelajaran lebih menarik, (2) ada kesempatan belajar mandiri di bawah bimbingan pembelajar, (3) memudahkan mempelajari setiap kompetensi yang harus dikuasai.

Pengembangan dalam konteks penelitian atau disebut penelitian pengembangan merupakan usaha mengembangkan dan menghasilkan produk yang dapat berupa materi, media, alat dan atau strategi pembelajaran yang diperuntukkan mengatasi pembelajaran di kelas atau laboratorium (Tegeh, dkk., 2015). Maksud dari pengembangan adalah meningkatkan kualitas proses dan hasil belajar baik dari sisi substansi materi maupun metode atau strateginya. Rohmah dkk. (2017) mengemukakan bahwa pengembangan buku ajar yang dimanfaatkan sebagai media dan atau sumber belajar dapat meningkatkan hasil belajar siswa. Hal senada juga diungkapkan oleh Solehun dkk. (2017) bahwa terdapat peningkatan hasil belajar yang signifikan dengan penggunaan buku ajar yang dikembangkan sesuai dengan kebutuhan dan karakteristik mahasiswa. Dengan demikian dapat ditarik benang merah bahwa pengembangan buku ajar tidak asal namun memerlukan perancangan yang sistematis mengacu pada sistem pembelajaran, desain pesan, metode atau strategi dan memperhatikan karakteristik pebelajar. Melihat hasil pengembangan berupa produk untuk kegiatan pembelajaran maka dapat dikatakan buku ajar memang khusus dikembangkan untuk kegiatan pembelajaran.

Model ADDIE merupakan model desain sistem pembelajaran yang khusus dirancang untuk menghasilkan produk maupun instrumen pembelajaran yang dapat berupa media, alat, strategi atau metode untuk memecahkan permasalahan pembelajaran. Model ADDIE memiliki prosedur tahapan yang jelas dan rinci. Branch, R.M. (dalam Habibi, M.W., dkk., 2016) mengemukakan tahapan-tahapan model ADDIE mencakup kegiatan Analyze (analisis), Design (desain), Development (pengembangan), Implementation (implementasi) dan Evaluate (evaluasi). 


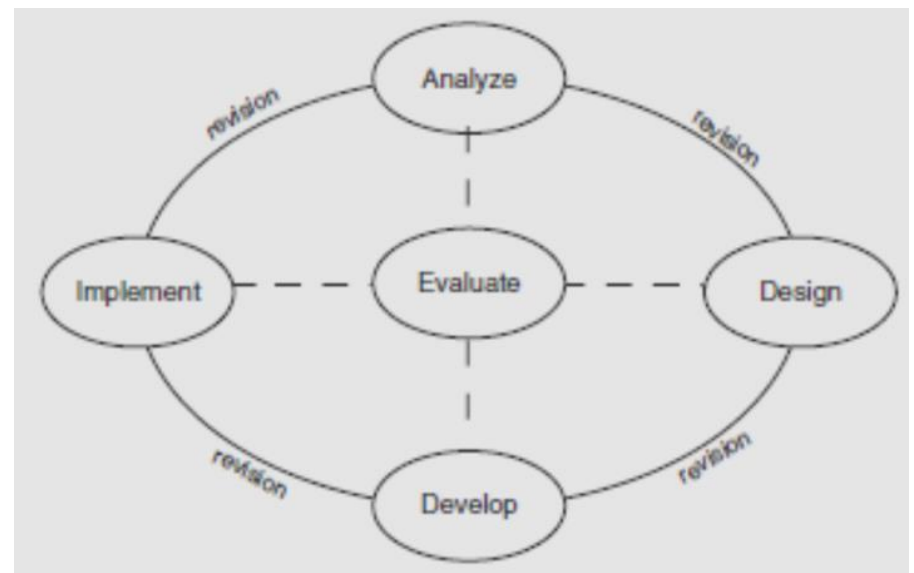

Gambar 1. Tahapan Desain Model ADDIE

\section{Analysis (analisis)}

Pada tahap analysis (analisa) yaitu melakukan needs assessment (analisis kebutuhan), mengidentifikasi masalah (kebutuhan), dan melakukan analisis tugas (task analysis). Output yang dihasilkan pada tahap ini adalah berupa identifikasi kesenjangan dan kebutuhan, karakteristik atau profil calon pebelajar serta analisis tugas yang rinci didasarkan atas kebutuhan.

\section{Design (desain/perancangan)}

Pada tahap desain ini, dilakukan dengan merancang komponen-komponen dalam sistem pembelajaran yang mencakup merumuskan tujuan pembelajaran, merancang materi, menyusun tes, menentukan strategi pembelajaran dan media yang dibutuhkan serta melihat sumber-sumber pendukung lain untuk keterlaksanaannya. Hasil tahap ini dituangkan dalam desain blue-print atau draft dokumen yang jelas dan rinci.

\section{Development (pengembangan)}

Pengembangan adalah proses mewujudkan blue-print alias desain menjadi kenyataan. Satu langkah penting dalam tahap pengembangan adalah uji coba sebelum diimplementasikan. Tahap uji coba pada tahap ini melibatkan ahli-ahli dibidang kelimuan yang diperlukan sehingga produk pengembangan sesuai yang diharapkan.

\section{Implementation (penerapan)}

Tahap implementasi adalah langkah nyata untuk menerapkan sistem pembelajaran atau produk yang telah dikembangkan. Artinya, pada tahap ini produk yang telah dikembangkan diset sedemikian rupa sesuai dengan peran atau fungsinya agar bisa diimplementasikan. Implementasi produk digunakan pada sasaran sebenarnya.

\section{Evaluation (evaluasi/umpanbalik)}

Evaluasi yaitu proses untuk melihat apakah sistem pembelajaran atau produk yang dikembangkan berhasil, sesuai dengan harapan awal atau tidak. Tahap evaluasi bisa dilakukan pada setiap empat tahap di atas. Evaluasi yang terjadi pada setiap empat tahap di atas disebut evaluasi formatif, karena tujuannya untuk kebutuhan revisi. Evaluasi merupakan langkah terakhir dari model desain sistem pembelajaran ADDIE. Evaluasi 
adalah sebuah proses yang dilakukan untuk memberikan nilai terhadap program atau produk pembelajaran.

Pengembangan buku ajar Evaluasi Pembelajaran menggunakan model ADDIE. Kenapa menggunakan model ADDIE? model ini dapat digunakan untuk merancang pembelajaran yang cocok untuk kegiatan pembelajaran mulai dari tingkat pendidikan dasar sampai dengan perguruan tinggi. Angko dan Mustaji (2013) membuktikan bahwa pengembangan bahan belajar dengan model ADDIE mampu meningkatkan hasil belajar siswa Sekolah Dasar. Hasil studi empiris serupa terkait penggunaan desain model ADDIE dilakukan oleh Wijayanto dan Santoso (2018) pada tingkat Sekolah Menengah Pertama, Suratno, dkk. (2018) pada tingkat Sekolah Menengah Atas dan Juliana, dkk. (2016) pada tingkat Perguruan Tinggi menunjukkan bahwa bahan ajar yang dikembangkan dengan model ADDIE dapat meningkatkan hasil belajar dan dapat digunakan untuk memecahkan masalah pembelajaran.

Berdasar pada studi empirik di atas, model ADDIE layak dipilih dalam pengembangan buku ajar Evaluasi Pembelajaran oleh karena model ini berorientasi pada pendekatan sistem, mengacu pada komponen sistem pembelajaran, dan memiliki langkah-langkah yang jelas dan pasti serta ada kesempatan merevisi untuk perbaikan hasil. Dengan demikian buku ajar yang dikembangkan dengan model ADDIE akan mampu menjawab kesulitan mahasiswa dalam perkuliahan Evaluasi Pembelajaran.

\section{METODE PENELITIAN}

Penelitian ini menggunakan metode pengembangan yang mengacu pada desain model ADDIE mencakup kegiatan Analyze (analisis), Design (desain), Development (pengembangan), Implementation (implementasi) dan Evaluate (evaluasi).

\section{Rancangan Penelitian}

Rancangan penelitian mengacu pada prosedur desain pengembangan model ADDIE dengan tahapan sebagai berikut:

1. Analisis

Pada tahap ini dilakukan analisis kebutuhan mahasiswa STKIP PGRI Trenggalek yang menempuh mata kuliah Evaluasi Pembelajaran terhadap media atau sumber yang tersedia, menganalisis karakteristik mata kuliah Evaluasi Pembelajaran pada kurikulum program studi, melakukan analisis tugas dan menganalisis karakteristik mahasiswa.

2. Desain

Pada tahap desain dilakukan kegiatan merancang spesifikasi media evaluasi pembelajaran sesuai kebutuhan mahasiswa, yakni mendesain spesifikasi buku ajar yang memuat komponen-komponen pembelajaran. Kegiatan tahap ini mencakup merancang: tujuan perkuliahan, pengorganisasian materi, menentukan strategi atau metode penyampaian materi, aktivitas belajar (latihan atau tugas belajar) dan evaluasinya. 


\section{Pengembangan}

Tahap pengembangan dilakukan dengan mengembangkan spesifikasi buku ajar sesuai tahap desain serta dilakukan uji coba kelayakan produk pada ahli. Uji ahli dilakukan pada: (1) ahli materi dan (2) ahli media.

4. Implementasi

Tahap implementasi dilakukan dengan mengujicobakan buku ajar evaluasi pembelajaran pada sasaran sebenarnya yakni mahasiswa. Mahasiswa yang dilibatkan pada tahap ini dikelompokkan menjadi 2 yakni (1) uji coba kelompok 1 dan (2) uji coba kelompok 2.

5. Evaluasi

Pada tahap ini dilakukan evaluasi buku ajar berdasarkan hasil implementasi pada mahasiswa untuk menentukan tindak lanjutnya sebagai revisi final buku ajar.

\section{Objek Penelitian}

Penelitian ini dilaksanakan di STKIP PGRI Trenggalek dengan populasi semua mahasiswa Program Studi yang menempuh mata kuliah Evaluasi Pembelajaran. Subjek coba pada objek penlitian ini mencakup (1) ahli materi 1 orang sesuai bidang keahlian, (2) ahli media 1 orang sesuai bidang keahlian, (3) kelompok 1 mahasiswa 60 orang dengan kriteria pemilihan mahasiswa yang memiliki prestasi tinggi, sedang dan rendah berdasarkan IPK dan (4) kelompok 2 mahasiswa 163 orang.

\section{Metode Pengumpulan Data}

Metode pengumpulan data dalam penelitian ini adalah menggunakan angket kuesioner tertutup dan kuesioner terbuka. Angket kuesioner tertutup untuk mendapatkan data kuantitatif berupa data numerik dengan menyediakan pilihan jawaban untuk dipilih oleh subjek coba. Angket kuesioner terbuka untuk mendapatkan data kualitatif berupa data deskripsi jawaban tertulis dari tanggapan komentar maupun saran dari subjek coba.

\section{Teknik Pengumpulan Data}

Teknik pengumpulan data dirancang dengan tahapan desain uji coba yang dilakukan secara bertahap dengan cara memberikan buku ajar kepada subyek coba yang disertai angket (kuesioner tertutup dan kuesioner terbuka). Tahapan desain uji coba terhadap subjek coba dimulai dari: (1) ahli materi bidang studi, (2) ahli media pembelajaran, (3) uji coba kelompok 1 mahasiswa dan (4) uji coba kelompok 2 mahasiswa.

\section{Teknik Analisis Data}

Teknik analisis data digunakan 2 teknik yaitu: (1) teknik analisis deskriptif kualitatif untuk mengolah data yang berupa tanggapan maupun saran perbaikan yang ada pada angket terbuka dari subyek coba, dan (2) analisis deskriptif kuantitatif untuk mengolah data angka dari angket tertutup dalam bentuk deskriptif. 
Rumus untuk mengolah data dalam bentuk persentase adalah sebagai berikut.

$$
V=\frac{T S e}{T S h} \times 100 \%
$$

Keterangan:

$\mathrm{V}=$ Persentase validasi

TSe $=$ Total skor empirik yang diperoleh

TSh = Total skor maksimum yang diharapkan

(Akbar, 2013)

Analisis data lanjutan yaitu penghitungan validasi gabungan diperoleh dengan menggunakan rumus sebagai berikut.

$$
V_{t o t}=\frac{\sum\left(V_{1}+V_{2}+V_{3}+V_{4} \ldots+V_{n}\right)}{n}
$$

Keterangan:

$\mathrm{V}_{\text {tot }} \quad=$ Persentase validasi total/gabungan

$\mathrm{V}_{1} \quad=$ Persentase validasi hasil kelompok responden ahli materi

$\mathrm{V}_{2} \quad=$ Persentase validasi hasil kelompok responden ahli media

$\mathrm{V}_{3} \quad=$ Persentase validasi hasil kelompok 1 responden mahasiswa

$\mathrm{V}_{4} \quad=$ Persentase validasi hasil kelompok 2 responden mahasiswa

$\mathrm{n}=$ Jumlah kelompok responden

(Akbar, 2013)

Hasil penghitungan dari rumus supaya dapat dimaknai maka digunakan ketetapan kriteria pada tabel 1 .

Tabel 1. Kriteria Kelayakan

\begin{tabular}{ccl}
\hline No & \multicolumn{1}{c}{ Angka } & \multicolumn{1}{c}{ Kategori } \\
\hline 1 & $85,01 \%-100 \%$ & Sangat valid/layak, artinya dapat digunakan tanpa revisi \\
\hline 2 & $70,01 \%-85,00 \%$ & $\begin{array}{l}\text { Cukup valid/layak, artinya dapat digunakan tetapi perlu } \\
\text { revisi kecil }\end{array}$ \\
\hline 3 & $50,01 \%-70,00 \%$ & $\begin{array}{l}\text { Kurang valid/layak, artinya disarankan tidak digunakan } \\
\text { sebab perlu revisi besar }\end{array}$ \\
\hline 4 & $01,00 \%-50,00 \%$ & Tidak valid/layak, artinya tidak dapat digunakan \\
\hline
\end{tabular}

(Akbar, 2013) 


\section{HASIL DAN PEMBAHASAN}

\section{Hasil Penelitian}

Penelitian pengembangan mengacu pada model ADDIE yakni Analyze (analisis), Design (desain), Development (pengembangan), Implementation (implementasi) dan Evaluate (evaluasi).

Pada proses analisis, peneliti melakukan analisis kebutuhan dengan cara menggali data dari subjek penelitian melalui sebaran angket dan wawancara. Hasil dari tahap ini berupa identifikasi kebutuhan awal mahasiswa terhadap media yang dibutuhkan dalam perkuliahan. Hasilnya tampak pada tabel 2 berikut.

Tabel 2. Hasil Kebutuhan Awal

\begin{tabular}{|c|c|c|c|c|c|c|}
\hline \multirow{3}{*}{$\begin{array}{c}\text { No } \\
1 .\end{array}$} & \multicolumn{2}{|l|}{ Pertanyaan } & \multicolumn{3}{|c|}{ Persentase Jawaban } & \multirow[b]{2}{*}{$>3$ Buah } \\
\hline & Jumlah referensi & 0 Buah & $1 \mathrm{Buah}$ & 2 Buah & 3 Buah & \\
\hline & $\begin{array}{l}\text { yang digunakan oleh } \\
\text { dosen }\end{array}$ & $0 \%$ & $26,67 \%$ & $43,33 \%$ & $16,67 \%$ & $13,33 \%$ \\
\hline \multirow[t]{2}{*}{2.} & \multirow{2}{*}{$\begin{array}{l}\text { Jumlah referensi } \\
\text { yang dicari sendiri } \\
\text { oleh mahasiswa }\end{array}$} & 0 Buah & 1 Buah & 2 Buah & 3 Buah & $>3$ Buah \\
\hline & & $33,33 \%$ & $63,33 \%$ & $3,33 \%$ & $0 \%$ & $0 \%$ \\
\hline \multirow[t]{2}{*}{3.} & \multirow{2}{*}{$\begin{array}{l}\text { Kemudahan } \\
\text { memahami materi } \\
\text { referensi }\end{array}$} & Sangat Mudah & Mudah & Cukup & Sulit & Sangat Sulit \\
\hline & & $6,67 \%$ & $13,33 \%$ & $33,33 \%$ & $36,7 \%$ & $10 \%$ \\
\hline \multirow[t]{2}{*}{4.} & \multirow{2}{*}{$\begin{array}{l}\text { Pemberian contoh } \\
\text { aplikatif pada buku } \\
\text { referensi }\end{array}$} & Tidak ada & Sedikit & Cukup & Banyak & Sangat Banyak \\
\hline & & $20 \%$ & $10 \%$ & $53 ’ 33 \%$ & $10 \%$ & $6,67 \%$ \\
\hline \multirow[t]{2}{*}{5.} & \multirow{2}{*}{$\begin{array}{l}\text { Referensi sesuai } \\
\text { kebutuhan materi } \\
\text { mahasiswa }\end{array}$} & $\begin{array}{l}\text { Sangat Tidak } \\
\text { Sesuai }\end{array}$ & $\begin{array}{l}\text { Tidak } \\
\text { Sesuai }\end{array}$ & Cukup & Sesuai & Sangat Sesuai \\
\hline & & $0 \%$ & $16,67 \%$ & $66,67 \%$ & $10 \%$ & $6,67 \%$ \\
\hline \multirow[t]{2}{*}{6.} & \multirow{2}{*}{$\begin{array}{l}\text { Referensi sesuai } \\
\text { dengan karakteristik } \\
\text { Program Studi }\end{array}$} & $\begin{array}{l}\text { Sangat Tidak } \\
\text { Sesuai }\end{array}$ & $\begin{array}{l}\text { Tidak } \\
\text { Sesuai }\end{array}$ & Cukup & Sesuai & Sangat Sesuai \\
\hline & & $0 \%$ & $43,33 \%$ & $40 \%$ & $16,67 \%$ & $0 \%$ \\
\hline \multirow[t]{2}{*}{7.} & \multirow{2}{*}{$\begin{array}{l}\text { Kebutuhan referensi } \\
\text { yang sesuai Program } \\
\text { Studi }\end{array}$} & $\begin{array}{l}\text { Sangat Tidak } \\
\text { Butuh }\end{array}$ & $\begin{array}{l}\text { Tidak } \\
\text { Butuh }\end{array}$ & Cukup & Butuh & Sangat Butuh \\
\hline & & $0 \%$ & $3,33 \%$ & $43,33 \%$ & $30 \%$ & $23,33 \%$ \\
\hline \multirow[t]{2}{*}{8.} & \multirow{2}{*}{$\begin{array}{l}\text { Persetujuan } \\
\text { Mahasiswa terkait } \\
\text { pengembangan } \\
\text { produk }\end{array}$} & $\begin{array}{l}\text { Sangat Tidak } \\
\text { Setuju }\end{array}$ & $\begin{array}{l}\text { Tidak } \\
\text { Setuju }\end{array}$ & Cukup & Setuju & Sangat Setuju \\
\hline & & $0 \%$ & $0 \%$ & $13,33 \%$ & $30 \%$ & $56,67 \%$ \\
\hline
\end{tabular}

Sumber: data penelitian 2019

Dari hasil sebaran kuesioner untuk mengetahui kebutuhan awal mahasiswa dapat dilihat bahwa lebih dari separuh populasi menyetujui pengembangan buku ajar evaluasi pembelajaran. Meskipun pertanyaan tentang kualitas referensi yang mereka gunakan menggambarkan bahwa itu cukup bagi populasi, tetapi dari segi kuantitas referensi yang digunakan oleh dosen tidak terlalu banyak karena tidak lebih dari $30 \%$ dosen yang menggunakan 3 atau lebih referensi. Kemandirian mahasiswa dalam mencari referensi 
yang sesuai kebutuhan juga masih rendah, hal ini ditunjukkan sebanyak 63\% mahasiswa hanya memiliki 1 referensi tambahan. Selanjutnya dari hasil wawancara dengan mahasiswa dapat dirangkum bahwa mahasiswa mengharapkan adanya media sebagai sumber belajar yang mudah dimanfaatkan dan sesuai dengan perkuliahan.

Hasil analisis karakteristik mata kuliah evaluasi pembelajaran adalah mata kuliah ini merupakan mata kuliah wajib tempuh oleh mahasiswa semua program studi dan bobot mata kuliah sebanyak dua sks. Mata kuliah ini merupakan mata kuliah prasyarat untuk menempuh mata kuliah lanjutan. Substansi mata kuliah mencakup dasar konsep, teori, prinsip dan prosedur dalam mengevaluasi pembelajaran. Tujuan dari mata kuliah evaluasi pembelajaran adalah mahasiswa memiliki kemampuan dalam melaksanakan evaluasi pembelajaran bidang studi. Guna mencapai kompetensi tersebut, diperlukan pengorganisasian pembalajarannya dengan menyajikan materi yang bersifat umum ke khusus disertai tugas-tugas sebagai aktivitas belajar mahasiswa sesuai konteksnya, baik yang sifatnya individu maupun kelompok.

Hasil analisis karakeristik mahasiswa peserta perkulihan evaluasi pembelajaran adalah mereka rata-rata berusia 19-20 tahun. Cara belajar mereka bervariasi dengan membuat catatan materi, menjadikan buku teks sebagai penunjang untuk mencari informasi sendiri selain informasi yang diperoleh dari dosen, suka diskusi kelas dan dapat belajar secara individu dan kelompok baik di kampus maupun di rumah. Mahasiswa memiliki motivasi belajar terhadap materi evaluasi pembelajaran karena berhubungan dengan bidang kerja mereka nantinya, yakni sebagai guru.

Hasil tahap desain dengan merancang draft spesifikasi buku evaluasi pembelajaran yang mengacu pada prinsip komponen sistem pembelajaran, prinsip visual dan kebahasaan. Buku ajar Evaluasi Pembelajaran yang dikembangkan memuat komponen tujuan perkuliahan, pengorganisasian materi, paparan materi, contoh-contoh, rangkuman, latihan untuk aktivitas belajar, evaluasi dan kunci jawaban sebagai umpan balik. Hoshangabadwala (2015) menunjukkan hasil persepsi siswa tentang layout buku teks yang memuat tujuan belajar, sajian materi dengan ilustrasi gambar serta warna, rangkuman, aktivitas belajar, dan latihan soal dapat menarik pebelajar untuk belajar sesuai kebutuhannya. Hal ini sejalan dengan pendapat Abidin (2014) yang menjelaskan bahwa aspek penyajian buku ajar hendaknya mendorong pebelajar aktif belajar sehingga mampu mendorong kreatifitas dan keaktifan mereka untuk berpikir dan bernalar.

Bahasa yang digunakan dalam buku ajar Evaluasi Pembelajaran sebagai alat penyampaian materi mengacu pada kaidah bahasa Indonesia dan disesuaikan dengan tingkat perkembangan mahasiswa. Abidin (2014) mengungkapkan bahwa bahasa buku ajar menggunakan bahasa Indonesia yang baik dan benar, serta struktur dan isi bahasa harus sesuai dengan tingkat penguasaan bahasa pebelajar. Pendapat serupa diungkapkan oleh Hasruddin et al. (2014) bahwa struktur kalimat yang digunakan dalam buku ajar 
harus mampu menggambarkan isi pesan yang ingin disampaikan tidak mengandung makna ganda dan informasi yang tidak relevan.

Pengembangan buku ajar Evaluasi Pembelajaran mengacu pada penggunaan prinsip visual. Penggunaan visual dalam buku ajar ini termasuk penggunaan gambar diagram, tabel dan foto yang disesuaikan dengan konteks isi teksnya atau materi evaluasi pembelajaran. Bobek, E., dan Tversky, B. (2016) mengungkapkan bahwa penjelasan materi disertai dengan visual dapat mempermudah pebelajar menguasai materi secara menyeluruh.

Penggunaan warna dalam desain buku ajar yang dikembangkan tidak serta merta dipilih begitu saja namun mengacu pada persepsi psikologi. Warna merupakan bagian dari elemen sebuah desain visual yang dapat memberikan stimulus serta dapat menciptakan impresi bagi pembaca. Smaldino (dalam Febrianto, 2012) memberikan alasan-alasan terkait dengan penggunaan warna dalam menyajikan materi yakni: (1) menambah realitas, (2) membedakan antara unsur-unsur sebuah visual, (3) memfokuskan perhatian pada isyarat-isyarat yang relevan, (4) mengkodekan dan mengaitkan secara logis unsur-unsur yang berkaitan, dan (5) menarik perhatian dan menciptakan repons emosional. Selanjutnya Sujarwo dan Oktaviana (2017) mengemukakan bahwa materi yang disajikan dengan menggunakan warna memiliki pengaruh positif terhadap short term memory pebelajar. Penyajian materi yang disertai warna mampu membantu pebelajar menguatkan retensinya terhadap materi yang dipelajarinya. Dengan demikian dasar penggunaan warna dalam pengembangan buku ajar Evaluasi Pembelajaran mengarah pada esensi peran warna yang memiliki peran penting dalam penyajian materi buku ajar.

Hasil tahap pengembangan adalah mencetak draft desain buku ajar sesuai spesifikasi yang telah ditentukan. Selanjutnya dilakukan uji coba pada ahli bidang keilmuan untuk mendapatkan kelayakan. Ahli yang dilibatkan dalam uji coba yakni ahli bidang materi dan ahli media.

Uji coba produk buku ajar dilakukan kepada 1 orang ahli materi untuk mengetahui kelayakan produk terkait dengan segi sistematika materi, kelengkapan materi, tujuan dari tiap-tiap materi, kemudahan memahami materi, dan kemampuan produk dalam memberikan kesempatan kepada mahasiswa untuk mengecek pemahaman mereka sendiri. Hasil uji ahli materi tampak pada tabel 3.

Tabel 3. Hasil Uji Ahli Materi

\begin{tabular}{clc}
\hline No. & \multicolumn{1}{|c}{ Variabel yang Dinilai } & $\begin{array}{c}\text { Total } \\
\text { Skor }\end{array}$ \\
\hline 1 & Ketepatan judul tiap bab dengan isi materi tiap bab & 5 \\
\hline 2 & Ketepatan pengorganisasian materi & 5 \\
\hline
\end{tabular}




\begin{tabular}{llc}
\hline 3 & $\begin{array}{l}\text { Kesesuaian antara tujuan pembelajaran umum (standar } \\
\text { kompetensi) dengan tujuan pembelajaran khusus }\end{array}$ & 5 \\
\hline 4 & $\begin{array}{l}\text { Kesesuaian antara tujuan pembelajaran dengan paparan } \\
\text { materi }\end{array}$ & 3 \\
\hline 5 & Kejelasan uraian materi & 3 \\
\hline 6 & Kejelasan contoh-contoh & 4 \\
\hline 7 & Kesesuaian antara tabel, bagan, gambar/ilustrasi dan materi & 4 \\
\hline 8 & Ketepatan isi rangkuman & 4 \\
\hline 9 & $\begin{array}{l}\text { Kesesuaian antara evaluasi/tes akhir bab dan tujuan } \\
\text { pembelajaran }\end{array}$ & 4 \\
\hline 10 & $\begin{array}{l}\text { Ketepatan jawaban tes sebagai umpan balik evaluasi/tes } \\
\text { akhir }\end{array}$ & 4 \\
\hline
\end{tabular}

\section{Sumber: data peneltian 2019}

Hasil uji coba dari ahli materi didapatkan skor persentase $82,00 \%$. Artinya jika dilihat pada tabel 1 kriteria kelayakan termasuk kategori cukup layak namun memerlukan sedikit revisi. Skor tersebut menunjukkan bahwa produk layak untuk diujicobakan ke lapangan. Saran dari ahli materi adalah beri latihan soal pada tiap BAB agar pengguna dapat mengecek sendiri sampai sejauh mana pemahaman mahasiswa. Terkait dengan respon saran ahli materi maka buku ajar ini direvisi dengan memberi latihan pada tiaptiap babnya sebagai aktivitas belajar belajar mahasiswa untuk mengetahui pemahaman mahasiswa.

Uji coba produk buku ajar dilakukan kepada 1 orang ahli media untuk mengetahui kelayakan produk terkait kemenarikan produk, penataan, pemilihan warna dan pemilihan jenis font yang digunakan dalam produk. Adapun hasilnya terdapat pada tabel 4.

Tabel 4. Hasil Uji Ahli Media

\begin{tabular}{clc}
\hline No. & \multicolumn{1}{c}{ Variabel yang Dinilai } & $\begin{array}{c}\text { Total } \\
\text { Skor }\end{array}$ \\
\hline 1 & Kualitas bahan buku ajar & 5 \\
\hline 2 & Kemenarikan desain buku ajar & 3 \\
\hline 3 & Kejelasan tulisan & 4 \\
\hline 4 & Kelengkapan komponen-komponen pada setiap bab buku ajar & 4 \\
\hline 5 & Ketepatan cara penyajian materi & 4 \\
\hline 6 & $\begin{array}{l}\text { Ketepatan penggunaan bagan, tabel, atau gambar-gambar } \\
\text { ilustrasi }\end{array}$ & 5 \\
\hline 7 & Kejelasan urutan penyajian materi & 4 \\
\hline 8 & Kesesuaian bahasa buku ajar dengan sasaran & 5 \\
\hline 9 & Kemudahan penggunaan buku ajar & 4 \\
\hline
\end{tabular}




\begin{tabular}{rcc}
\hline Jumlah & 38 \\
\hline Persentase Skor (\%) & 84,44 \\
\hline
\end{tabular}

Sumber: data peneltian 2019

Hasil uji coba dari ahli media didapatkan skor persentase 84,44\%. Artinya jika dilihat pada tabel 1 kriteria kelayakan termasuk kategori cukup layak namun memerlukan sedikit revisi. Skor tersebut menunjukkan bahwa produk layak diujicobakan ke lapangan. Saran dari ahli media adalah cover sebaiknya diganti dengan desain yang terkesan milenial agar dapat lebih menarik atensi calon pembaca. Terkait dengan respon saran ahli media maka buku ajar ini direvisi dengan mengubah sampul supaya menarik dan kekinian.

Pada tahap implementasi dilakukan dengan mengujicobakan buku ajar pada sasaran sebenarnya yakni mahasiswa peserta perkuliahan. Mahasiswa yang dilibatkan pada tahap ini dikelompokkan menjadi 2 yakni (1) uji coba kelompok 1 dan (2) uji coba kelompok 2.

Uji coba I produk buku ajar dilakukan kepada 60 orang mahasiswa untuk mengetahui kelayakan produk terkait kemenarikan dan isi buku ajar. Adapun hasilnya terdapat pada tabel 5.

Tabel 5. Hasil Uji Coba I

\begin{tabular}{clc}
\hline No. & \multicolumn{1}{c}{ Variabel yang Dinilai } & $\begin{array}{c}\text { Total } \\
\text { Skor }\end{array}$ \\
\hline 1 & Kemenarikan desain buku ajar & 234 \\
\hline 2 & Kejelasan tulisan buku ajar dan petunjuk penggunaannya & 210 \\
\hline 3 & Kejelasan tujuan pembelajaran & 270 \\
\hline 4 & $\begin{array}{l}\text { Kemudahan organisasi materi pada bagian awal membantu } \\
\text { memahami kerangka isi materi }\end{array}$ & 264 \\
\hline 5 & $\begin{array}{l}\text { Kesesuaian antara tujuan pembelajaran dengan paparan } \\
\text { materi }\end{array}$ & 252 \\
\hline 6 & Kejelasan uraian materi tiap bab & 240 \\
\hline 7 & $\begin{array}{l}\text { Kejelasan contoh untuk membantu memahami materi } \\
\text { Kejelasan antara tabel, bagan, gambar/ilustrasi untuk } \\
\text { membantu memahami materi }\end{array}$ & 222 \\
\hline 9 & $\begin{array}{l}\text { Kejelasan isi rangkuman } \\
\text { Kejelasan tugas belajar/latihan untuk mencapai tujuan } \\
\text { pembelajaran }\end{array}$ & 204 \\
\hline 10 & $\begin{array}{l}\text { Kesesuaian evaluasi/tes akhir bab untuk mencapai tujuan } \\
\text { pembelajaran }\end{array}$ & 252 \\
\hline 12 & $\begin{array}{l}\text { Ketepatan adanya jawaban tes sebagai umpan balik } \\
\text { evaluasi/tes akhir }\end{array}$ & 258 \\
\hline
\end{tabular}




\section{Jumlah 2910 \\ Persentase Skor $(\%) \quad 80,83$}

\section{Sumber: data peneltian 2019}

Hasil uji coba I didapatkan skor persentase 80,83\%, artinya jika dilihat pada tabel 1 kriteria kelayakan termasuk kategori cukup layak namun memerlukan sedikit revisi. Saran hasil uji I ini berhubungan dengan ukuran buku ajar yang berukuran A4 terlalu besar, petunjuk penggunaan buku ajar dan petunjuk aktivitas belajar yang kurang jelas. Berhubungan dengan komentar saran masukan dari uji I mahasiswa maka buku ajar direvisi dengan mengubah ukuran buku menjadi ukuran B5 dan memperjelas petunjuk penggunaan buku ajar serta petunjuk aktivitas belajar supaya buku ajar mudah digunakan dan mampu memberikan respon sesuai harapan pengguna.

Uji coba II produk buku ajar dilakukan kepada 163 orang mahasiswa untuk mengetahui kelayakan produk terkait kemenarikan dan isi buku ajar. Adapun hasilnya terdapat pada tabel 6.

Tabel 6. Hasil Uji Coba II

\begin{tabular}{|c|c|c|}
\hline No. & Variabel yang Dinilai & $\begin{array}{l}\text { Total } \\
\text { Skor }\end{array}$ \\
\hline 1 & Kemenarikan desain buku ajar & 704 \\
\hline 2 & Kejelasan tulisan buku ajar dan petunjuk penggunaannya & 591 \\
\hline 3 & Kejelasan tujuan pembelajaran & 689 \\
\hline 4 & $\begin{array}{l}\text { Kemudahan organisasi materi pada bagian awal membantu } \\
\text { memahami kerangka isi materi }\end{array}$ & 725 \\
\hline 5 & Kesesuaian antara tujuan pembelajaran dengan paparan materi & 714 \\
\hline 6 & Kejelasan uraian materi tiap bab & 707 \\
\hline 7 & Kejelasan contoh untuk membantu memahami materi & 616 \\
\hline 8 & $\begin{array}{l}\text { Kejelasan antara tabel, bagan, gambar/ilustrasi untuk membantu } \\
\text { memahami materi }\end{array}$ & 682 \\
\hline 9 & Kejelasan isi rangkuman & 724 \\
\hline 10 & $\begin{array}{l}\text { Kejelasan tugas belajar/latihan untuk mencapai tujuan } \\
\text { pembelajaran }\end{array}$ & 702 \\
\hline 11 & $\begin{array}{l}\text { Kesesuaian evaluasi/tes akhir bab untuk mencapai tujuan } \\
\text { pembelajaran }\end{array}$ & 697 \\
\hline \multirow[t]{3}{*}{12} & $\begin{array}{l}\text { Ketepatan adanya jawaban tes sebagai umpan balik evaluasi/tes } \\
\text { akhir }\end{array}$ & 692 \\
\hline & Jumlah & 8243 \\
\hline & Persentase Skor (\%) & 84,28 \\
\hline
\end{tabular}

Sumber: data peneltian 2019

Hasil uji coba II didapatkan skor persentase 84,28\%, artinya jika dilihat pada tabel 1 kriteria kelayakan termasuk kategori cukup layak namun memerlukan sedikit revisi. Komentar saran dari hasil uji II ini berhubungan dengan terdapatnya tulisan pada isi bab 
III dan bab VI yang kurang jelas keterbacaannya dan contoh yang kurang mewakili keilmuan mahasiswa pada program studi yang ada. Revisi terkait dengan komentar saran tersebut adalah memperbaiki buku ajar dengan cetak ulang dan menambahkan contoh sesuai keilmuan masing-masing program studi.

Hasil tahap evaluasi dilakukan dengan melihat hasil ujicoba secara menyeluruh. Hasil secara keseluruhan produk buku ajar dengan penghitungan gabungan dari hasil masing-masing uji subjek coba didapatkan skor persentase $82,88 \%$. Artinya jika dilihat pada tabel kriteria kelayakan termasuk kategori cukup layak. Dengan demikian buku ajar Evaluasi Pembelajaran dapat digunakan sebagai media belajar untuk mahasiswa STKIP PGRI Trenggalek.

Secara keseluruhan hasil uji kelayakan buku ajar Evaluasi Pembelajaran disajikan dalam gambar diagram berikut.

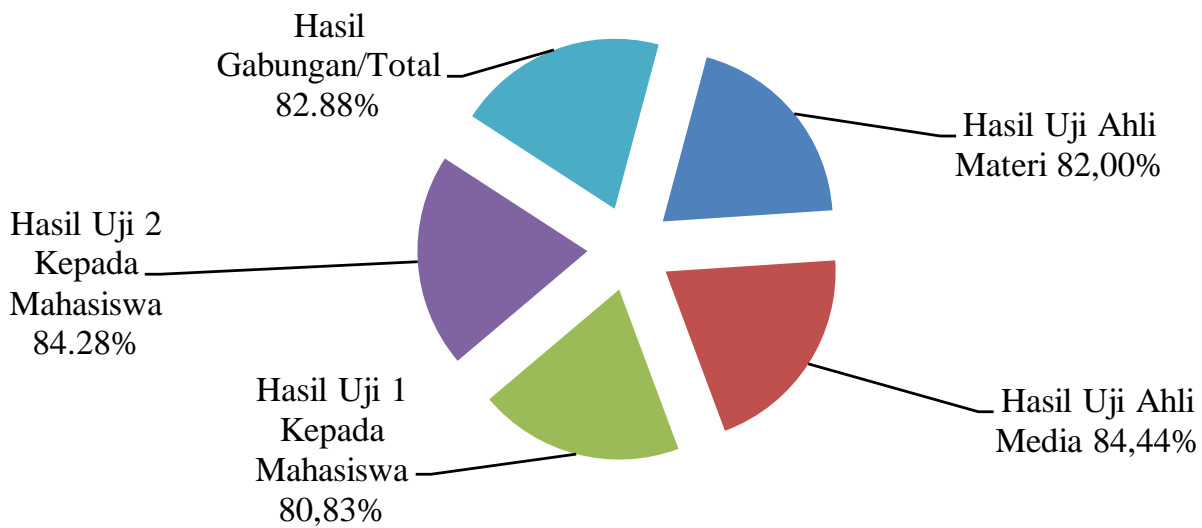

Gambar 2. Hasil Uji Kelayakan Buku Ajar

Pengembangan produk buku ajar Evaluasi Pembelajaran dengan model ADDIE dapat memecahkan masalah belajar mahasiswa STKIP PGRI Trenggalek. Artinya buku ajar ini dapat memenuhi kebutuhan mahasiswa akan media belajar yang mudah dimanfaatkan dalam perkuliahan. Model ADDIE sebagai model desain sistem pembelajaran diorientasikan untuk memecahkan masalah pembelajaran yang sistemik dengan menggunakan pendekatan sistem mulai dari penganalisisan, perancangan, pengembangan, pelaksanaan dan pengevaluasian. Tegeh, I.M, dkk. (2015) menjelaskan hasil risetnya tentang buku ajar yang dikembangkan sesuai dengan langkah-langkah model ADDIE dapat digunakan untuk pembelajaran. Lebih lanjut kajian empiris dari Hadi dan Agustina (2016) dan Habibi, M.W., dkk. (2016) menunjukkan bahwa produk buku ajar yang disusun sesuai dengan kebutuhan mampu memudahkan pebelajar membangun konsep pengetahuannya sendiri. 


\section{KESIMPULAN}

Buku ajar Evaluasi Pembelajaran yang dikembangkan sesuai prosedur tahapan desain model ADDIE yang mencakup Analyze (analisis), Design (desain), Development (pengembangan), Implementation (implementasi) dan Evaluate (evaluasi) serta memperhatikan prinsip visual, kaidah kebahasaan dan penataan layoutnya cukup layak digunakan mahasiswa sebagai media penunjang proses perkuliahan dan dapat mengakomodasi kesulitan mahasiswa dalam mencari referensi yang mudah sesuai perkuliahan. Saran terkait hasil penelitian adalah diperlukan penelitian lanjutan untuk menguji keefektifan produk buku ajar ini serta dikembangkan juga ke dalam media berbasis elektronik mengingat mahasiswa sering menggunakan media berbasis teknologi.

\section{DAFTAR RUJUKAN}

Abidin, Y. 2014. Desain Sistem Pembelajaran dalam Konteks Kurikulum 2013. Bandung: Refika Aditama.

Akbar, S. 2013. Instrumen Perangkat Pembelajaran. Bandung: PT Remaja Rosdakarya. Angko, N., dan Mustaji. 2013. Pengembangan Bahan Ajar dengan Model ADDIE untuk Mata Pelajaran Matematika Kelas SDS Mawar Sharon Surabaya. Jurnal Kwangsan, (Online), 1 (1): 1-15. (https://jurnalkwangsan. kemdikbud.go.id) diakses 3 September 2019.

Bobek, E., and Tversky, B. 2016. Creating Visual Explanations Improves Learning. PMC Journal, $\quad$ (Online), $\quad 1 \quad$ (27): $\quad 1-27 . \quad$ (https://www.ncbi. nlm.nih.gov/pmc/articles/PMC5256450/?report=classic) diakses 10 September 2019.

Febrianto, R. 2012. Pengembangan Bahan Ajar Mata Kuliah Strategi Belajar Mengajar untuk Mahasiswa Program Studi PPKn Jurusan PIPS di STKIP Trenggalek. Tesis tidak Diterbitkan. Malang: PPS UM.

Habibi, M.H., Suarsini, E., dan Amin, M. 2016. Pengembangan Buku Ajar Matakuliah Mikrobiologi Dasar. Jurnal Pendidikan, (Online), 1 (5): 890-900. (http://journal.um.ac.id)_diakses 5 September 2019.

Hadi, H., dan Agustina, S. 2016. Pengembangan Buku Ajar Geografi Desa-Kota Menggunakan Model ADDIE. Jurnal Ilmu Kependidikan, (Online), 11 (1): 90105. (http://e-journal.hamzanwadi.ac.id) diakses 19 September 2019. 
Hasruddin, Pratiwi, N., \& Harahap, F. 2014. The Development of Problem-Based Applied Microbiology Textbook. International Journal of Education and Research, 2 (9): 187-194. (https://www.ijern.com) diakses 12 September 2019.

Hoshangabadwala, A. 2015. Student Perceptions of Textbook Layout and Learnability in Private Schools. Journal of Education and Educational Development, (Online), 2 (1): 1-16. (https://journals.iobmresearch.com) diakses 12 September 2019.

Istiqlal, A. 2018. Manfaat Media Pembelajaran dalam Proses Belajar dan Mengajar Mahasiswa di Perguruan Tinggi. Jurnal Kepemimpinan dan Pengurusan Sekolah, (Online), 3 (2): 139-144. (https://stkip-pessel.ac.id) diakses 28 Agustus 2019.

Juliana, K., Amin, M., dan Suarsini, E. 2016. Pengembangan Buku Ajar Matakuliah Biologi Sel dengan Pendekatan Bioinformatika untuk Mahasiswa S1 Pendidikan Biologi Universitas Negeri Malang. Jurnal Pendidikan, (Online), 1 (9): 16771683. (https://journal.um.ac.id) diakses 25 September 2019.

Novauli, Feralys. 2015. Kompetensi Guru Dalam Peningkatan Prestasi Belajar Pada SMP Negeri Dalam Kota Banda Aceh. Jurnal Administrasi Pendidikan, (Online), 3 (1): 45-67. (http://jurnal.unsyiah. ac.id) diakses 30 Agustus 2019. Prastowo, Andi. 2013. Panduan Kreatif Membuat Bahan Ajar Inovatif. Jogjakarta: DIVA Press.

Rohmah, D.N., Hariyono dan Sudarmiatin. 2017. Pengembangan Buku Ajar IPS SD Berbasis Kontekstual. Jurnal Pendidikan, (Online), 2 (5): 719-723, (https://journal.um.ac.id) diakses 28 Nopember 2019.

Solehun, Yulianto, B., dan Suhartono. 2017. Pengembangan Buku Ajar Mata Kuliah Bahasa Indonesia Berorientasi Pendekatan Saintifik untuk Meningkatkan Kompetensi Mahasiswa S1 PGSD. Jurnal Review Pendidikan Dasar, (Online), 3 (1): 329-338. (https://journal.unesa.ac.id) diakses 30 Nopember 2019.

Sujarwo, S., dan Oktaviana, R. 2017. Pengaruh Warna Terhadap Short Term Memory Pada Siswa Kelas VIII SMP N 37 Palembang. Jurnal Psikologi Islami, (Online), 3 (1): 33-42. (https://jurnal.radenfatah.ac.id) diakses 10 September 2019.

Suratno, Narulita, E., dan Luthfia, S. 2018. Pengembangan Buku Siswa Berbasis Kontekstual Bermuatan Nilai-Nilai Agama Islam Pada Materi Bioteknologi Kelas XII SMA/MA. Jurnal Edukasi, (Online), V (1): 45-48, (https://jurnal.unej.ac.id) diakses 5 Oktober 2019. 
Tegeh, I.M., Jampel, I.N. dan Pudjawan, K. 2015. Pengembangan Buku Ajar Model Penelitian Pengembangan dengan Model ADDIE. Senari, (Online), 3: 208-216. (http://eproceeding.undiksha.ac.id.) diakses 21 September 2019.

Umarella, S., Saimima, M.S., dan Hussein, S. 2018. Urgensi Media Dalam Proses Pembelajaran. al-Iltizam: Jurnal Pendidikan Agama Islam, (Online), 3 (2): 234241. (https://jurnal.iainambon.ac.id) diakses 25 Agustus 2019.

Wijayanto, R., dan Santoso, R.H. 2018. Pengembangan Bahan Ajar Matematika Dengan Pendekatan Problem Solving Berorientasi Pada Kemampuan Pemecahan Masalah. Jurnal Pendidikan Matematika, (Online), 7 (3), (https://journal.student.uny.ac.id) diakses 1 Oktober 2019. 
Volume 4, Nomor 1, Februari 2020 